\title{
The Effects of Household Processing on the Ascorbic Acid and Moisture Contents of Some Selected Nigerian Vegetables
}

\author{
${ }^{1}$ Edeh, R.I. ${ }^{2}$ Adeniji, P.O. and ${ }^{* 3}$ Salau B. A. \\ ${ }^{I}$ Department of Home Science, Nutrition and Dietetics, University of Nigeria, Nsukka, Nigeria \\ ${ }^{2}$ Department of Transport and Tourism Studies, College of Management sciences, Redeemer 's University, Km \\ 46, Lagos/Ibadan Expressway, PMB 3005, Redemption City Mowe, Ogun State, Nigeria \\ ${ }^{3}$ Department of Chemical Sciences, College of Natural Science, Redeemer's University, Km 46, Lagos/Ibadan \\ Expressway, PMB 3005, Redemption City Mowe, Ogun State, Nigeria
}

\begin{abstract}
The effect of household preparation prior to consumption was assessed in five vegetables commonly consumed in Nigeria: Telfaria occidentalis, Celosia argentea, Amaranthus caudatus, Solanum macrocarpon and Talinum triangulare purchased from a local market in south-west Nigeria. Wholesomeness, colour, moisture and ascorbic acid content were determined using standard laboratory procedures. The results obtained showed that the sizes of the shreds and time of exposure resulted in variation of the ascorbic acid content which ranges between $11 \%$ and $56 \%$ when compared with the fresh. And moisture content which ranges between $2 \%$ and $45 \%$. Thus, care must be exercised in the types of processes and exposure time during vegetables preparation.
\end{abstract}

Keywords: Vegetables, ascorbic acid, shredding, moisture content.

\section{Introduction}

Vegetables are plants or plant parts that are used as food (Harri and Franca, 2003). They are served either raw or cooked as part of the main course, apart from their nutritive value, they contribute texture and flavor to food and make the food more appetizing; and by proper choice of vegetables, methods of preparation, serving the meal can be made interesting and appealing.

Green leafy vegetables are one of the sources of nutrients for growth in man and animal (Fasuyi, 2006). The relative low cost of vegetables makes them a common component of main meals and side dishes eaten in Nigerian households. Thus, vegetables contribute enormously to the ascorbic acid nutritive of Nigerians since it is grown throughout the year and are relatively cheap and acceptable (Mellor, 2000).

However, losses that occur in the ascorbic acid content of vegetables during preparation and storage prior to cooking render some of the vegetables void of ascorbic acid at the time of consumption (Schippers, 2000). At times, values got from the food consumption tables for vegetables may not be reliable owing to the variable handling processes they might have been subjected to during preparation and storage. The ascorbic acid of vegetables also need to the quantified in relation to their preparation methods since any method that retains ascorbic acid would invariably affect other nutrients (Akpapunam, 2004).

In view of the above, we set to investigate the ascorbic acid content of vegetables at different level of processing in order to ascertain retention level during household processing.

\section{Materials And Methods}

Sample collection and preparation: 5 vegetable samples commonly consumed in Nigeria were randomly selected and purchased from Bodija market, Ibadan, Oyo state. The vegetables are Telfaria occidentalis, Celosia argentea, Amaranthus caudatus, Solanum macrocarpon and Talinum triangulare. Wholeness was determined by physical examination using texture and colour. Each of the samples were divided into 3 portions and labeled $\mathrm{A}, \mathrm{B}$, and $\mathrm{C}$ respectively for each sample.

Samples in group A were left unshredded but exposed to air inside the room for 6 hours while samples in group $\mathrm{B}$ and $\mathrm{C}$ were shredded into slices of $1 \mathrm{~cm}$ and $3 \mathrm{~cm}$ respectively and also exposed to air inside the room for 6 hours before their moisture and ascorbic acid contents were determined.

Analysis

I Moisture determination: The moisture content of both the fresh and processed samples were determined using the air oven method as described by AOAC (1990).

II Ascorbic acid determination: The ascorbic acid compositions of the samples were determined by the derivative of dehydroascorbic acid with method of 2, 4-dinitrophenylhydrazine and the products were measured using colorimeter.

All the samples analyzed in each group received uniformed treatment and were analyzed in triplicates. 
III Data Analysis: The data generated from the experiments were analyzed statistically using mean, standard deviation, analysis of variance, difference of means and percentages.

\section{Results}

TABLE 1: ASCORBIC ACID CONTENTS (Mg/100g) IN GREEN LEAFY VEGETABLES AND PERCENTAGE DIFFERENCE FROM FRESH VEGETABLES.

\begin{tabular}{llll}
\hline Vegetable & Fresh vegetable & $3 \mathrm{~cm} \mathrm{Shredded} \mathrm{vegetable}$ & $1 \mathrm{~cm}$ Shredded vegetable \\
\hline $\begin{array}{l}\text { Telfaria Occidentalis } \\
\text { Percentage difference from fresh }\end{array}$ & $63.00 \pm 1.75^{\mathrm{c}}$ & $53.08 \pm 1.01^{\mathrm{b}}$ & $28.00 \pm 1.75^{\mathrm{a}}$ \\
Celosia argentea & $15.75 \pm 1.75^{\mathrm{b}}$ & 15.75 & 55.56 \\
Percentage difference from fresh & & $13.42 \pm 1.01^{\mathrm{a}, \mathrm{b}}$ & $9.92 \pm 1.01^{\mathrm{a}}$ \\
Amaranthus caudatus & $39.08 \pm 1.01^{\mathrm{c}}$ & 14.79 & 37.03 \\
Percentage difference from fresh & & $27.42 \pm 1.01^{\mathrm{b}}$ & $25.08 \pm 1.75^{\mathrm{a}}$ \\
Solanum macrocarpon & $17.50 \pm 1.75^{\mathrm{b}}$ & 29.84 & 35.82 \\
Percentage difference from fresh & & $12.25 \pm 1.75^{\mathrm{a}}$ & $10.50 \pm 1.75^{\mathrm{a}}$ \\
Talinum triangulare & $26.25 \pm 1.75^{\mathrm{b}}$ & 30.00 & 40.00 \\
Percentage difference from fresh & & $23.30 \pm 1.01^{\mathrm{b}}$ & $13.42 \pm 2.02^{\mathrm{a}}$ \\
\hline
\end{tabular}

Values with different superscripts in the same role are significantly different at $p<0.05$. Values in parenthesis represented in percentage decrease $(-)$ and increase $(+)$ when compared with fresh vegetable.

\section{TABLE 2: MOISTURE CONTENTS (\%) OF GREEN LEAFY VEGETABLES AND PERCENTAGE} DIFFERENCE FROM FRESH VEGETABLES.

\begin{tabular}{llll}
\hline Vegetable & Fresh vegetable & $3 \mathrm{~cm}$ Shredded vegetable & $1 \mathrm{~cm}$ Shredded vegetable \\
\hline Telfaria Occidentalis & $87.21 \pm 1.35^{\mathrm{b}}$ & $57.84 \pm 8.00^{\mathrm{a}}$ & $47.54 \pm 4.41^{\mathrm{a}}$ \\
Percentage difference from fresh & & 33.68 & 45.49 \\
$\begin{array}{l}\text { Celosia argentea } \\
\text { Percentage difference from fresh }\end{array}$ & $92.35 \pm 2.11^{\mathrm{b}}$ & $86.38 \pm 1.94^{\mathrm{a}, \mathrm{b}}$ & $79.89 \pm 3.58^{\mathrm{a}}$ \\
Amaranthus caudatus & & 6.46 & 13.49 \\
Percentage difference from fresh & $83.95 \pm 1.07^{\mathrm{b}}$ & $62.66 \pm 5.43^{\mathrm{a}}$ & $58.25 \pm 2.27^{\mathrm{a}}$ \\
Solanum macrocarpon & & 25.36 & 30.61 \\
Percentage difference from fresh & $85.19 \pm 2.01^{\mathrm{b}}$ & $74.54 \pm 4.56^{\mathrm{a}, \mathrm{b}}$ & $64.30 \pm 2.04^{\mathrm{a}}$ \\
Talinum triangulare & $96.00 \pm 2.55$ & 12.50 & 24.52 \\
Percentage difference from fresh & & $93.13 \pm 0.35$ & $93.86 \pm 1.49$ \\
\hline
\end{tabular}

Values with different superscripts in the same role are significantly different at $p<0.05$. values in parenthesis represented in percentage decrease $(-)$ and increase $(+)$ when compared with fresh vegetable.

\section{Discussion}

Studies have shown the effect of various processing methods on nutrient content of food (Odufuwa et al., 2013; Salau et al., 2010), Ascorbic acid is one of the most labile nutrient which its level after processing indicate substantial retention of other nutrients and is affected by oxygen, light, heat and various other treatments which foods are subjected to (Kreutler and Czajka-Narins, 1987). This study showed that shredding of vegetables reduced the ascorbic acid content after exposure to air with maximal lost recorded in $1 \mathrm{~cm}$ shreds. High loss of ascorbic acid in $3 \mathrm{~cm}$ shredded vegetable was observed in Solanum macrocarpon (30\%) followed by Armaranthus caudatus (29.84\%), Telfaria occidentalis (15.75\%), Celosia argentea (14.79\%) while the lowest loss was observed in Talinum triangulare (11.24\%). $3 \mathrm{~cm}$ shredding and exposure to six 6 hours of air has no significant effect $(\mathrm{p}>0.05)$ on ascorbic acid loss in Talinum triangulare and Celosia argentea. Thus, these two vegetables could be shredded at $3 \mathrm{~cm}$ without significant loss of ascorbic acid. Also, Telfaria occidentalis was capable of withstanding $3 \mathrm{~cm}$ shredding with little loss in ascorbic acid (i.e $15.75 \%$ loss).

At $1 \mathrm{~cm}$ shredding, highest ascorbic acid was observed in Telfaria occidentalis $(56.56 \%)$ followed by Talinum triangulare (48.88\%) while the lower values were observed in Solanum macrocarpon (40.00\%), followed by Celosia argentea (37.03\%) and the lowest in Amaranthus caudatus (35.83). this implies that Amaranthus caudatus has the highest capacity of withstanding shredding and exposure to air in terms of ascorbic acid loss, while Telfaria occidentalis has the lowest capacity of withstanding ascorbic acid loss in such processing method. It is therefore expedient not to shred Telfaria occidentalis and Talinum triangulare beyond 3 $\mathrm{cm}$ which Celosia argentea and Amaranthus caudatus could withstand reasonably.

The moisture content of vegetable goes a long way in determining the perishability with a direct correlation, while determining the nutrient density in an inverse order (Salau et al., 2011). The highest water content was observed Talinum triangulare (96.00\%) followed by Celosia argentea (92.35\%), Telfaria occidentalis (87.21\%), Solanum macrocarpon 85.19\%) and the lowest in Amaranthus caudatus (83.95\%). At $3 \mathrm{~cm}$ shredding the highest loss was observed in Telfaria occidentalis (33.68\%) followed by Amaranthus caudatus (25.36\%), Solanum macrocarpon (12.50\%), Celosia argentea $(6.46 \%)$ and the least value was observed in Talinum triangulare $(2.99 \%)$. This result suggests that Talinum triangulare has highest moisture 
retention under $3 \mathrm{~cm}$ shredding and exposure to six hour preparation and the least was observed in Telfaria occidentalis.

At $1 \mathrm{~cm}$ shredding and six hours exposure to air, highest loss of moisture was observed in Telfaria occidentalis (45.49\%) followed by Amaranthus caudatus (30.61\%), Solanum macrocarpon (24.52\%), Celosia argentea $(13.49 \%)$ while the least was Talinum triangulare with moisture content of 2.23 . Comparing $3 \mathrm{~cm}$ and $1 \mathrm{~cm}$ shreds, it was shown in the data that was no significant difference $(\mathrm{p}>0.05)$ when the two shreds $(1 \mathrm{~cm}$ and $3 \mathrm{~cm}$ ) were exposed to six hours air. However, this implies shredding below $3 \mathrm{~cm}$ may neither contribute significantly to water loss nor drying of such vegetables when exposure to six air-drying.

\section{Conclusion}

Data obtained from this study showed that the common household preparation methods of vegetables though useful in increasing the aesthetic value of dishes are detrimental to their ascorbic acid content, some vegetables being more susceptible to these losses than others. The study showed that ascorbic acid retention is higher with minimal shredding of the vegetables.

\section{References}

[1]. Akpapunam, M.A. (2004): Effects of blanching and storage temperatures on ascorbic acid and total carotenoids content of some Nigerian fresh vegetables. Quality plantarum for Human Nutrition 34(3):177-180.

[2]. AOAC (1990): Official Analytical Methods. Association of Official Analytical Chemistry.Adapted by Association of Ascorbic acidhemists (Methods of Vitamin Assay. $3^{\text {rd }}$ Ed). Ins. Chapt. 14

[3]. Fasuyi A.O. (2006): Nutritional Properties of some Tropical Vegetable Leaf Meals, Chemical Characterization and Functional Pproperties. Afr. J. Biotec, 5: 49-58.

[4]. Harri Vainio, Franca Bianchini (2003), Fruits And Vegetables, IARC, p. 2

[5]. Kreutler PA and Czajka-Narins DM (1987) Nutrition in Perspective, 2nd edition. Englewood Cliffs, New Jersey: Prentice Hall.

[6]. Mellor S. (2000) :Herbs and spices promote health and growth, vegetables in progress, Vol.16(1)

[7]. Odufuwa, Kuburat Temitope, Atunnise Adeleke, Kinnah, Hudson joseph, Adeniji P. O, Salau, Bamidele Adewale (2013). Changes in Saponins Content of Some Selected Nigerian Vegetables during Blanching and Juicing. IOSR Journal Of Environmental Science, Toxicology And Food Technology; 3(3)38-42.

[8]. Salau, B. A, Ajani E .O, Odufuwa, K. T, Adegbesan, B. O, and Soladoye, M. O. (2010). Effect of processing on iodine content of some selected plants food. African Journal of Biotechnology; 9(8) 1200-1204.

[9]. Salau B. A, Emmanuel O. Ajani, Michael O. Soladoye and Bisuga Nurudeen A., (2011). Evaluation of iodine content of some selected fruits and vegetables in Nigeria. African Journal of Biotechnology Vol. 10(6), pp. 960-964,

[10]. Schippers R...R.(2009): African indigenous vegetables : an overview of the cultivated species. Natural Resources Institute/ACP-EU Technical Centre for Agricultural and Rural cooperation, Chatham U.K. 